\title{
HUBUNGAN PERTUNJUKAN TEATER DENGAN PERILAKU PENONTON
}

\section{THEATER SHOWING RELATIONSHIP WITH WATCHTOR BEHAVIOR}

\author{
M Niswan'1, H Bilada1 ${ }^{1}$, Sukarelawati1a \\ 1 Universitas Djuanda Bogor, Jawa Barat, Indonesia \\ a Korespondensi: Sukarelawati, Email: sukarelawati@unida.ac.id \\ (Diterima: 26-03-2018; Ditelaah: 28-03-2018; Disetujui: 18-10-2018)
}

\begin{abstract}
This study focuses on the relationship of a theater performance consisting of message sources, message content and message format with the audience behavior of Bogor City. This research was conducted at the Kamuning Gading Art Building at members of the Bogor Theater Campus Family. The objectives of the research are (1) to find out the source of messages in the theater, (2) to find out the content of messages in the theater, (3) to find out the message format in the theater, and (4) to analyze the relationship between message sources, content and message format in theater performances with audience behavior. Analysis of variables in this study using quantitative analysis, this study uses associativecausal methods. Data was collected using a questionnaire. Descriptive data analysis uses weight means score, and to test the relationship between variables using Rank Spearman's statistical test. The results of the study showed the source, content and format of the message in the theater, which influenced the behavior of the theater audience. This affects the audience in giving cognitive, affective and behavioral effects in seeing theater performances.
\end{abstract}

Keywords: behavior, message source, message content, message format.

\begin{abstract}
ABSTRAK
Penelitian ini memfokuskan pada hubungan suatu pertunjukan teater yang terdiri dari sumber pesan, isi pesan dan format pesan dengan perilaku penonton Kota Bogor. Penelitian ini dilakukan di Gedung Kesenian Kamuning Gading pada anggota Keluarga Teater Kampus Bogor. Tujuan dari penelitian adalah (1) untuk mengetahui sumber pesan dalam teater, (2) untuk mengetahui isi pesan dalam teater, (3) untuk mengetahui format pesan dalam teater, dan (4) untuk menganalisis hubungan antara sumber pesan, isi dan format pesan dalam pertunjukan teater dengan perilaku penonton. Analisa variabel dalam penelitian ini menggunakan analisa kuantitatif, Penelitian ini menggunakan metode asosiatif-kausal. Data dikumpulkan menggunakan kuisioner. Analisis data deskriptif menggunakan weight means score, dan untuk menguji hubungan antara variabel menggunakan uji statistik Rank Spearmans. Adapun hasil penelitian menunjukan pada sumber, isi dan format pesan dalam teater, yang mempengaruhi pada perilaku penonton teater. Hali ini mempengaruhi penonton dalam memberikan efek kognitif, afektif dan behavioral dalam melihat pertunjukan teater.

Kata kunci: format pesan, isi pesan, perilaku, sumber pesan.
\end{abstract}

Niswan, M., Bilada, H., \& Sukarelawati. (2018). Hubungan Pertunjukan Teater dengan Perilaku Penonton. Jurnal Sosial Humaniora 9(2): 138-143. 


\section{PENDAHULUAN}

Komunikasi merupakan dasar bagi seluruh interaksi antar manusia. Tanpa komunikasi, sebuah interaksi antar manusia baik kelompok, maupun organisasi tidak mungkin terjadi. Komunikasi merupakan hubungan kontak antara manusia baik individu maupun kelompok. Komunikasi adalah bagian dari kehidupan manusia, karena manusia sejak dilahirkan sudah berkomunikasi dengan lingkungannya. Komunikasi bukan sekedar tukar menukar pikiran serta pendapat saja, akan tetapi kegiatan yang dilakukan untuk berusaha mengubah pendapat dan tingkah laku orang lain.

Fungsi bahasa sebagai alat komunikasi telah memperlihatkan otonomi kekuasaannya dalam proses-proses pembentukan sejarah, ideology politik dan kematian, agama dan kesusastraan. Plato diseret ke tiang gantung karena menggunakan bahasa yang berbeda dengan kehendak penguasa. Para martir dalam sufisme dari Al-Hallaj sampai Syekh Siti Jenar mengalami nasib yang sama, juga disebabkan oleh persepsi bahasa yang berbeda. (Salad, 2000). Kutipan di atas dipahami, bahwa penggunaan bahasa, dapat mengubah persepsi orang berbeda dengan makna yang dimaksudkan oleh komunikator.

Lakon teater atau jalannya teater sebenarnya mengandung pesan atau ajaran, terutama ajaran moral bagi penontonnya. Penonton menemukan ajaran itu secara tersirat dalam lakon drama. (Wiyanto, 2002)

Teater merupakan tiruan kehidupan manusia yang diproyeksikan di atas pentas. Melihat teater, penonton seolah melihat kejadian dalam masyarakat. Kadang-kadang konflik yang disajikan dalam teater sama dengan konflik batin mereka sendiri. Lakon teater sebenarnya mengandung pesan atau ajaran (terutama ajaran moral) bagi penontonnya. Penonton menemukan ajaran itu secara tersirat dalam lakon teater (waluyo, 2002)

Menonton suatu pertunjukan teater sering terjadi penonton dapat memahami jalan cerita, walaupun ada kata-kata atau kalimat yang kurang dipahami. Ini dimungkinkan karena pembicaraan dalam dialog suatu teater diikuti oleh mimik dan gerak-gerik serta intonasi yang kurang jelas oleh pelaku yang memainkan perannya dengan baik. Melalui teater, selain dapat mempelajari dan menikmati hasilnya, orang juga dapat memahami masalah yang disodorkan di dalamnya tentang masyarakat melalui dialog-dialog pelaku sekaligus belajar tentang isi pesan teater tersebut dan juga mempertinggi pengertian mereka tentang bahasa lisan. Sehingga nilainilai pesan yang terkandung di dalamnya mudah diserap oleh penonton (Waluyo, 2002).

Dengan fenomena diatas peneliti tertarik untuk melakukan penelitian terkait dengan Hubungan pertunjukan teater dengan perilaku penonton. Peneliti mengajukan rumusan masalah: (1) bagaimana sumber pesan dalam teater? (2) bagaimana isi pesan dalam teater? (3) bagaimana format pesan dalam teater? (4) bagaimana hubungan sumber pesan, isi pesan dan format pesan dalam teater dengan perilaku penonton?.

Adapun tujuan dan manfaatnya sebagai berikut: (1) untuk mengetahui sumber pesan dalam teater, (2) untuk mengetahui isi pesan dalam teater, (3) untuk mengetahui format pesan dalam teater, dan (4) untuk menganalisis hubungan antara sumber pesan, isi dan format pesan dalam pertunjukan teater dengan perilaku penonton.

Manfaat penelitian ini dapat mengembangkan pemahaman yang lebih luas dalam bidang ilmu komunikasi terkait dengan informasi yang disampaikan melalui media pertunjukan teater, dapat menjadi bahan studi dan evaluasi bagi pelaku teater dalam menyampaikan pesan sehingga timbulnya perilaku terhadap penonton. 


\section{MATERI DAN METODE}

\section{Materi}

Teater berasal dari kata teatron (bahasa Yunani), artinya tempat melihat (Romawi, auditorium; tempat mendengar). Atau, area yang tinggi tempat meletakan sesajian untuk para dewa. Amphiteater di Yunani adalah sebuah tempat pertunjukan. Bisa memuat sekitar 100.000 penonton. (Riantiarno, 2011).

Sumber pesan berbicara tentang siapa yang menjadi sumber pesan (who should say $i t$ ). Sumber pesan dalam teater merupakan sebuah penyampaian pesan terlebih kedalam ilmu peran yang dipegang oleh aktor dalam berteater, aktor pun menghidupkan kembali kisah dengan beragam keterampilan dan alat bantu, seperti pengubahan suara, ekspresi wajah, gerak tubuh, menjadi sangat penting dalam penyampaian isi pesan).

Isi pesan berbicara mengenai apa yang dikatakan (what to say). Jika dikaitkan dengan isi pesan dalam teater, isi pesan yang mencakup semua ide atau gagasan, bahkan tema dalam pertunjukan teater dikemas dalam sebuah naskah pertunjukan, dimana naskah itu harus menceritakan atau menjabarkan sebuah isi pesan baik moral atau bercerita tentang kehidupan seharihari (Riantiarno, 2011)

Format pesan berbicara tentang bagaimana mengatakan pesan secara simbolis (how to say it simbolically). Format pesan harus kuat (Riantiarno, 2003). Pesan dibawakan dalam televisi atau langsung secara personal, semua elemen tersebut ditambah bahasa tubuh (petunjuk nonverbal) harus direncanakan. Diantarannya gerak tubuh, tata rias, vocal, tata busana, dan tata suara. Jika pesan ada pada produk atau kemasan produk, maka komunikator harus memperhatikan tata panggung dan tata lampu.

\section{Komponen Perilaku}

Komponen kognitif adalah perilaku yang berhubungan dengan gejala mengenai pikiran. Ini berarti perilaku berwujud pengetahuan, Pemahaman individu tentang objek atau kelompok objek tertentu. Contoh pengetahuan pesan yang didapat setelah melihat pertunjukan teater (Diana, 2008)

Komponen afektif berwujud proses yang menyangkut perasaan-perasaan tertentu seperti Sikap, simpati, antipati, dan sebagainya yang ditujukan kepada objekobjek tertentu. Contoh setelah mengetahui pesan yang ada pada pertunjukan teater, seorang penonton merasa suka untuk menonton pertunjukan teater (Diana,2008).

Komponen konatif atau behavioural bersangkutan dengan niat, upaya, usaha yang cenderung menjadi suatu keputusan dan tindakan. Behavioral berwujud proses tendensi atau kecenderungan untuk berbuat sesuatu misalkan kecenderungan untuk meonton. komponen behavioural dipengaruhi oleh komponen kognitif yang memiliki kecenderungan untuk bertindak (konatif) (Diana,2008).

\section{Metode}

Metode penelitian yang digunakan yaitu penelitian asosiatif dengan hubungan kausal. penelitian asosiatif merupakan penelitian yang bertujuan untuk mengetahui hubungan antara dua variable atau lebih. Hubungan kausal adalah hubungan yang bersifat sebab akibat. Jadi terdapat variabel independen (variabel yang mempengaruhi) dan dependen (dipengaruhi), Sugiyono (2012). Populasi dalam penelitian ini adalah Keluarga Teater Kampus Bogor (KTKB) khususnya yang menjadi anggota dalam KTKB. Adapun teknik sampling yang digunakan dalam penelitian ini adalah teknik sampling jenuh atau sensus. Menurut Sugiyono (2008) Teknik sampling jenuh atau sensus adalah teknik penentuan sampel bila semua anggota populasi digunakan sebagai sampel.

Analisa variabel dalam penelitian ini digunakan analisa kuantitatif yaitu dengan statistik. Setelah data terkumpul dengan lengkap, data dikumpulkan menggunakan kuisioner. Analisis data deskriptif 
menggunakan weight means score, dan untuk menguji hubungan antara variabel menggunakan uji statistik Rank Spearmans.

\section{HASIL DAN PEMBAHASAN}

Pertunjukan teater memiliki peranan seperti sumber pesan, isi pesan dan format pesan, yang seimbang. Sehingga pertunjukan teater menjadi pesan yang disampaikan kepada penonton, pesan yang diterima oleh penonton pun berkaitan dengan keadaan, atau peritiwa yang pernah dialami penonton, perbedaannya hanya dikemas di sebuah panggung pertunjukan, sehingga menjadi sebuah hubungan tindakan atau keputusan penonton untuk melakukan pengambilan keputusan perilaku penonton.

Hasil penelitian mengenai hubungan pertunjukan teater dengan perilaku penonton menunjukan adanya hubungan antara variabel pengaruh $X$ sebagai Pesan teater dengan variabel $Y$ sebagai perilaku penonton yang ditujukan. Hasil nilai koefesien korelasi Ran Spearman`s antara variabel hubungan pertunjukan teater denga perilaku penonton sebesar 0.39** dengan arah positif pada indikator sangat rendah dalam interprestasi koefisien korelasi.

Adapun pengaruh yang diberikan oleh variabel $X$ pesan dalam teater hanya sebesar $8,85 \%$ pada variabel $Y$ yaitu perilaku penonton sesuai dengan hasil perhitungan koefisien determinasi. Dalam penelitian ini dapat disimpulkan beberapa faktor yang membuat ada hubungannya antara faktor $\mathrm{X}$ antara lain sebagai berikut.

1. Sumber pesan dalam teater atau aktor sudah baik dalam menjadi sumber pesan. Sehingga ide dan gagasan yang disampaikan aktor, memperlihatkan nilai baik dan benar dalam suatu permasalahan dapat diterima sangat baik oleh penonton.
2. Naskah atau isi pesan dalam teater sangat baik. Naskah menjadi pegangan seorang sumber pesan atau aktor, dalam menceritakan atau menyampaikan isi pesan, naskah teater itu sendiri menceritakan atau mengangkat peristiwa yang terjadi di masyarakat, adat, ataupun ruang lingkup pergaulan masyarakat, naskah berbicara tentang kehidupan sehari-hari sehingga penonton bisa memahamai dengan sangat baik.

3. Tata Artistik yang berhubungan dengan pengemasan ketika petunjukan teater, menjadi gambaran suatu pertunjukan teater dilihat sangat diperlukannya, gerak tubuh, mimik muka untuk memunculkan karakter aktor, sehingga perlu tata rias dan tata busana untuk memperkuat karakter tokoh seorang aktor, bahkan vocal pun harus diperhatikan karena baik bahasa yang diucapkan menggunakan artikulasi, intonasi, serta diksi akan menjadi faktor pemaparan pesan kepada penonton, dan tata panggung, tata suara serta tata cahaya menjadi akhir pengemasan sebuah pertunjukan, dimana menjadai faktor penguat keadaan, suasana, suatu pertunjukan. Sehingga penonton bisa menikmati pertunjukan teater secara sempurna.

Selanjutnya untuk mengetahui sejauh mana variabel hubungan pertunjukan teater (X) dengan Perilaku Penonton (Y) dalam penelitian ini, maka perlu digunakan perhitungan koefisien determinasi (Kd), yaitu :

$$
\begin{aligned}
K d & =\rho^{2} \times 100 \% \\
K d & =0,293^{2} \times 100 \% \\
K d & =0,0858 \times 100 \% \\
K d & =8,58 \%
\end{aligned}
$$

Dengan demikian besarnya kontribusi variabel independen terhadap variabel dependen sebesar 8,58\%, dan kontribusi faktor lain adalah sebesar 91,42\%. 


\section{KESIMPULAN DAN IMPLIKASI}

\section{Kesimpulan}

Berdasarkan hasil analisis data dan pembahasan yang telah diuraikan dengan permasalahan mengenai hubungan pertunjukan teater terhadap perilaku penonton keluarga teater kampus Bogor dapat disimpulkan bahwa:

1. Sumber pesan dalam teater adalah seorang aktor. Aktor dinyatakan menjadi sumber pesan yang baik dilihat dari kelayakan untuk dipercaya (trustworthiness) berkaitan dengan seberapa obyektifitas dan jujur sember pesan tersebut dirasakan oleh penonton. Sehingga ide dan gagasan yang disampaikan aktor, memperlihatkan nilai baik dan benar dalam suatu permasalahan dapat diterima sangat baik oleh penonton, tetapi aktorpun perlu memiliki kecerdasan dalam ilmu peran sehingga menjadi acuan dalam penyampaian pesan ketika pertunjukan teater.

2. Isi pesan dalam teater adalah sebuah naskah. Naskah dikatakan, disampaikan atau dipertanyakan sehingga isi pesan dapat diterima oleh penonton. Naskah menjadi pegangan seorang sumber pesan atau aktor, dalam menceritakan atau menyampaikan isi pesan, naskah teater itu sendiri menceritakan atau mengangkat peristiwa yang terjadi di masyarakat, adat, ataupun ruang lingkup pergaulan masyarakat, naskah berbicara tentang kehidupan sehari-hari sehingga penonton bisa memahamai dengan sangat baik, naskah pun sebagai pedoman seorang aktor dalam menyampaikan pesan sehingga menjadi isi pesan yang disampaikan sumbe pesan dalam pertunjukan teater.

3. Format pesan berbicara tentang bagaimana mengatakan pesan secara simbolis (how to say it simbolically). Yang dimana format pesan dalam teater adalah tata artistik, dimana artistik berhubungan dengan pengemasan ketika petunjukan teater, menjadi gambaran suatu pertunjukan teater dilihat sangat diperlukannya, gerak tubuh, mimik muka untuk memunculkan karakter aktor, sehingga perlu tata rias dan tata busana untuk memperkuat karakter tokoh seorang aktor, bahkan vocal pun harus diperhatikan karena baik bahasa yang diucapkan menggunakan artikulasi, intonasi, serta diksi akan menjadi faktor pemaparan pesan kepada penonton, dan tata panggung, tata suara serta tata cahaya menjadi akhir pengemasan sebuah pertunjukan, dimana menjadai faktor penguat keadaan, suasana, suatu pertunjukan. Sehingga penonton bisa menikmati pertunjukan teater secara sempurna.

4. Dapat disimpulkan bahwa hubungan pertunjukan teater terhadap perilaku penonton keluarga teater kampus bogor, berdasarkan hasil penelitian menunjukan bahwa hubungan variabel independen terhadap vareiabel dependen memiliki nilai koefisien korelasi antara variabel sumber pesan, isi pesan dan format pesan terhadap variabel efek kognitif, efek afektif dan efek behavioral, sebesar 0,039 dan menurut tabel interprestasi terhadap koefisien korelasi menunjukan hubungan yang sedang dan arah yang positif menunjukan hubungan yang sangat nyata antara kedua variabel tersebut walaupun memiliki hubungan yang sedang.

\section{Implikasi}

\section{Implikasi Teoretis}

Penelitian ini memberikan wawasan dan pengetahuan berkaitan dengan "hubungan pertunjukan teater dengan perilaku penonton" penelitian inipun berkaitan dengan teori Komunikasi kelompok, Pesan dan Efek Media (cognitif, afektif, behavioral) sehingga implikasi dari teori ini dapat terlihat di pembahasan 


\section{Implikasi Praktis}

Hasil penelitian ini digunakan sebagai masukan bagi pelaku teater terkait. Perenncanaan yang matang dalam membuat pertunjukan teater akan berdampak pada tujuan dan hasil yang sempurna. Pertunjukan teater menjadi penyampaian pesan dikatakan berhasil, jika pesan yang dimaksud dapat dimengerti oleh penerima, komunikan atau penonton. Akhirnya penulis berharap semoga Jurnal ini bermanfaat bagi pembaca umumnya dan penulis khususnya.

\section{DAFTAR PUSTAKA}

Ardianto, Drs. Elvinaro, M.Si. Komala, Dra. Lukiati, M.Si Karlina, Dra. Siti. M,Si. 2007. Komunikasi Massa suatu Pngantar Edisi Revisi. Bandung : Sembiosa Rekatama Media.

Hamid, Salad. 2000. Agama Seni. Yogyakarta: Yayasan semesta.
Nurudin. 2010. Sistem Komunikasi Indonesia. Jakarta : PT. Raja Prafindo.

Riantiarno, N. 2003. Menyentuh Teater: tanta jawab seputar teater kita. Jakarta : PT HM Sampoerna Tbk.

Riantiarno, N. 2011. Kitab Teater: tanya jawab seputar seni Pertunjukan. Jakarta : PT Gramedia Widia Sarana Indonesia.

Soekanto, Soerjono. 2003. Sosiologi: Suatu pengantar. Raja Grafindo, jakarta. Soekanto, Soerjono. 2003.

Sugiyono. 2008. Metode Penelitian Kunatitatif Kualitatif dan R\&D. Bandung Alfabeta.

Sugiyono. 2010, Statistika Untuk Penelitian, Cet ke-16 Bandung, Alfabeta.

Waluyo, Herman, J. 2002. Drama: Teori dan pengajarannya, Yogyakarta: PT Hanindita

Widjaja. A.H. 2000. Ilmu komunikasi: Pengantar studi. Jakarta : Rineta Cipta.

Wijaya, Putu. 2007. Teater. Jakarta: Lembaga Pendidikan Seni Nusantara.

Wiyanto, Asul. 2002. Terampil Bermain Drama. Jakarta : Grasindo Jakarta. 